\title{
Ethanolic Extract of Polish Propolis: Chemical Composition and TRAIL-R2 Death Receptor Targeting Apoptotic Activity against Prostate Cancer Cells
}

\author{
Ewelina Szliszka, ${ }_{1}^{1}$ Anna Sokół-Łętowska, ${ }^{2}$ Alicja Z. Kucharska, ${ }^{2}$ Dagmara Jaworska, \\ Zenon P. Czuba, ${ }^{1}$ and Wojciech Król ${ }^{1}$ \\ ${ }^{1}$ Department of Microbiology and Immunology, Medical University of Silesia in Katowice, Jordana 19, 41808 Zabrze, Poland \\ ${ }^{2}$ Department of Fruit and Vegetables and Cereals Technology, Wrocław University of Environmental and Life Sciences, \\ Chetmońskiego 47/41, 51630 Wrocław, Poland \\ Correspondence should be addressed to Wojciech Król; wkrol@sum.edu.pl
}

Received 10 June 2013; Accepted 18 September 2013

Academic Editor: Muhammad Nabeel Ghayur

Copyright $\odot 2013$ Ewelina Szliszka et al. This is an open access article distributed under the Creative Commons Attribution License, which permits unrestricted use, distribution, and reproduction in any medium, provided the original work is properly cited.

Propolis possesses chemopreventive properties through direct anticancer and indirect immunomodulatory activities. Tumor necrosis factor-related apoptosis-inducing ligand (TRAIL) plays a significant role in immunosurveillance and defense against cancer cells. TRAIL triggers apoptosis upon binding to TRAIL-R1 (DR4) and TRAIL-R2 (DR5) death receptors expressed on cancer cell surface. The activation of TRAIL apoptotic signaling is considered an attractive option for cancer prevention. However, as more tumor cells are reported to be resistant to TRAIL-mediated death, it is important to develop new strategies to overcome this resistance. The aim of this study was to investigate the chemical composition and proapoptotic mechanism of ethanolic extract of Polish propolis (EEP-P) against cancer cells. The identification and quantification of phenolic compounds in propolis extract were performed using HPLC-DAD and UPLC-Q-TOF-MS methods. TRAIL-resistant LNCaP prostate cancer cells were treated with EEP-P and TRAIL. Cytotoxicity was measured by MTT and LDH assays. Apoptosis was detected using annexin VFITC staining by flow cytometry and fluorescence microscopy. Death receptors expression was analyzed using flow cytometry. Pinobanksin, chrysin, methoxyflavanone, $p$-coumaric acid, ferulic acid and caffeic acid were the main phenolics found in EEP-P. Propolis sensitized LNCaP cells through upregulation of TRAIL-R2. These results suggest that EEP-P supports TRAIL-mediated immunochemoprevention in prostate cancer cells.

\section{Introduction}

The field of cancer prevention, defined as the long-term intervention with natural or synthetic molecules to inhibit, delay, or reverse carcinogenesis, is gaining increasing importance, especially at the time when use of complementary and alternative medicine (CAM) and natural health products is consistently growing. At present, CAM in oncology represents a challenging area of interest since remarkable scientific evidence suggests that natural agents can prevent the process of carcinogenesis and effectively influence the risk of cancer in humans [1-3]. Prostate cancer represents an ideal disease for chemopreventive strategies because of its long latency, late age of onset, relatively slow rate of growth and progression, high incidence, tumor marker availability, and identifiable preneoplastic lesions and risk groups $[4,5]$.

Propolis (bee glue) is a resinous hive product collected by honeybees from many plant sources. The chemical composition of propolis is complex and largely depends on the geographical origin and specific flora at the site of collection $[6,7]$. The main phenolics found in Polish propolis are phenolic acids, including cinnamic, $p$-coumaric, ferulic, and caffeic acid, caffeic acid phenylethyl ester (CAPE), and flavonoids, such as chrysin, tectochrysin, apigenin, pinocembrin, pinostrombin, pinobanksin, galangin, kaempferol, kaempferide, and quercetin [8-11]. Propolis cannot be used as raw material, and it must be purified by extraction to remove the inert material and preserve the phenolic fraction [9]. The ethanolic 
extract of propolis (EEP) exhibits chemopreventive properties through direct anticancer and indirect immunomodulatory properties $[9,12,13]$. EEP suppresses proliferation and tumor growth and induces cell-cycle arrest and apoptosis in prostate cancer cells $[9,14]$.

Tumor necrosis factor-related apoptosis-inducing ligand (TRAIL), a member of the TNF superfamily, is a powerful inducer of apoptosis in cancer cells without toxicity against normal tissues $[15,16]$. The death ligand is expressed on T lymphocytes, natural killer cells, neutrophils, monocytes, or macrophages $[17,18]$. Membrane-bound TRAIL can be cleaved from the cell surface into a soluble secreted form. Soluble or expressed on immune cells TRAIL plays an important role in surveillance and defense against tumor cells [19]. Endogenous TRAIL triggers apoptosis via receptor-mediated death through interaction with the death receptors (DRs) in cancer cells $[20,21]$. TRAIL initiates programmed death upon binding to TRAIL-R1 (DR4) and TRAIL-R2 (DR5) receptors and promotes recruitment of the adaptor molecule Fas-associated death domain (FADD) with formation of the death inducing signaling complex (DISC) and subsequent activation of the caspases cascade $[22,23]$.

The induction of cancer cell-specific apoptosis via the activation of TRAIL signaling has become an important focus of cancer research $[24,25]$. However, some cancer cells are resistant to TRAIL-induced death. Failure to undergo apoptosis has been implicated in resistance of cancer cells to TRAIL surveillance, tumor development, and progression. Multiple factors contribute to TRAIL resistance, including disorder in expression of DRs and proapoptotic or antiapoptotic proteins $[26,27]$. As more tumor cells are reported to be resistant to TRAIL-mediated death, it is needed to develop new strategies to overcome this resistance $[28,29]$. Polish and Brazilian EEP have been shown to sensitize prostate cancer cells to TRAIL-induced apoptosis $[9,30]$. TRAIL-R2 called death receptor 5 (DR5) or "KILLER" receptor is a crucial player in the transduction of apoptotic signaling in cancer cells derived from solid tumors [31, 32]. We hypothesize that this immunomodulation through targeting of TRAIL-R2 death receptor by propolis extracts is one of the mechanisms responsible for its cancer preventive effect.

The major aim of this study was to determine the chemical composition and the proapoptotic mechanism of ethanolic extract of Polish propolis (EEP-P) against cancer cells. We investigated the involvement of TRAIL-R2 in EEP$\mathrm{P}$ modulation of TRAIL-mediated apoptotic signaling in LNCaP prostate cancer cells.

\section{Materials and Methods}

2.1. General. Soluble recombinant human TRAIL was purchased from PeproTech Inc. (Rocky Hill, NJ, USA). Acetonitrile, formic acid, and dimethyl sulfoxide (DMSO) were obtained from Sigma-Aldrich (Steinheim, Germany). Acetonitrile for LC-MS was purchased from POCh (Gliwice, Poland). The following compounds were used as standards: caffeic acid and rhamnetin (Roth, Karlsruhe, Germany), apigenin, chrysin, galangin, pinobanksin, and $p$-coumaric acid (Sigma-Aldrich, Steinheim, Germany), and ferulic acid (Serva, Heidelberg, Germany).

2.2. Preparation of Polish Propolis Extract. Propolis was collected manually from beehive located in southern region in Poland (The Carpathians) and was kept desiccated pending its processing. As previously described, propolis sample was extracted in $95 \% \mathrm{v} / \mathrm{v}$ ethanol at $37^{\circ} \mathrm{C}$ for 4 days, in a hermetically closed glass vessel under occasional shaking. The ethanolic extract of Polish propolis (EEP-P) was then filtered through a Whatman filter paper no. 4 and evaporated in a rotary evaporator under reduced pressure at $60^{\circ} \mathrm{C}$. The same collection and extraction procedures were used throughout all our laboratory studies [9]. EEP-P was dissolved in DMSO $(50 \mathrm{mg} / \mathrm{mL})$, and the final concentration of DMSO in the culture medium was controlled at $0.1 \%(\mathrm{v} / \mathrm{v})$.

\subsection{Identification and Quantification of Phenolic Compounds} by HPLC-DAD Method. Phenolic compounds were determined using Dionex (USA) HPLC system equipped with diode array detector model Ultimate 3000, a quaternary pump LPG-3400A, autosampler EWPS-3000SI, and thermostated column compartment TCC-3000SD and controlled by Chromeleon v.6.8 software. The reversed phase Cadenza $5 \mathrm{CD}-\mathrm{C} 18(75 \mathrm{~mm} \times 4.6$ i.d.) column (Imtakt, Kyoto, Japan) with guard column Cadenza $(5 \times 4.6$ i.d. $)$ guard column (Imtakt, Kyoto, Japan) was used. The mobile phase was composed of (A) $0.1 \%(\mathrm{v} / \mathrm{v})$ formic acid in water and (B) acetonitrile. The applied elution conditions were $0 \mathrm{~min} 20 \%$ B; $0-10$ min linear gradient from $20 \%$ to $30 \%$ B; $10-40 \mathrm{~min}$ linear gradient from $30 \%$ to $40 \% \mathrm{~B} ; 40-60 \mathrm{~min}$, linear gradient from $40 \%$ to $60 \% \mathrm{~B} ; 60-80 \mathrm{~min}$, linear gradient from $60 \%$ to $80 \% \mathrm{~B}$; and then again the initial conditions [33]. The flow rate was $1 \mathrm{~mL} / \mathrm{min}$, and the injection volume was $20 \mu \mathrm{L}$. The column was operated at $30^{\circ} \mathrm{C}$. The compounds were monitored at $290 \mathrm{~nm}, 325 \mathrm{~nm}$, and $370 \mathrm{~nm}$.

\subsection{Identification and Quantification of Phenolic Compounds} by LC-MS Method. Compounds identification was performed on an Acquity ultraperformance liquid chromatography (UPLC) system coupled with a quadruple-time of flight (Q-TOF) MS instrument (UPLC/Synapt Q-TOF MS, Waters Corp., Milford, MA, USA) with an electrospray ionization (ESI) source. Separation was achieved on the Acquity BEH C18 column $(100 \mathrm{~mm} \times 2.1 \mathrm{~mm}$ i.d., $1.7 \mu \mathrm{m}$; Waters $)$. Detection wavelengths were set at 290, 325, and $370 \mathrm{~nm}$. A mobile phase was a mixture of $1.5 \%$ formic acid (A) and acetonitrile (B). The gradient program was as follows: initial conditions95\% (A), $12 \mathrm{~min}-5 \%$ (A), $13 \mathrm{~min}-5 \%$ (A), $14.5 \mathrm{~min}-95 \%$ (A), and $16 \mathrm{~min}-95 \%$ (A). The flow rate was $0.45 \mathrm{~mL} / \mathrm{min}$, and the injection volume was $5 \mu \mathrm{L}$. The column was operated at $30^{\circ} \mathrm{C}$. The major operating parameters for the Q-TOF MS were set as follows: capillary voltage $2.0 \mathrm{kV}$, cone voltage $45 \mathrm{~V}$, cone gas flow of $11 \mathrm{~L} / \mathrm{h}$, collision energy $50 \mathrm{eV}$, source temperature $100^{\circ} \mathrm{C}$, desolvation temperature $250^{\circ} \mathrm{C}$, collision gas, argon; desolvation gas (nitrogen) flow rate, $600 \mathrm{~L} / \mathrm{h}$; data acquisition range, $m / z 100-1.000 \mathrm{Da}$; ionization mode, 
negative [34]. The data were collected by Mass-Lynx V 4.1 software.

2.5. Cell Culture. The human androgen-dependent LNCaP prostate cancer cell line was obtained from the German Collection of Microorganisms and Cell Cultures (DSMZ, Braunschweig, Germany). Cells were maintained in RPMI 1640 medium supplemented with $10 \%$ heat-inactivated fetal bovine serum, $4 \mathrm{mM} \mathrm{L}$-glutamine, $100 \mathrm{U} / \mathrm{mL}$ penicillin, and $100 \mu \mathrm{g} / \mathrm{mL}$ streptomycin at $37^{\circ} \mathrm{C}$ and $5 \% \mathrm{CO}_{2}$ in a humidified incubator [35]. Reagents for cell culture were purchased from the American Type Culture Collection (Manassas, VA, USA).

2.6. Cytotoxicity Assay. Cytotoxicity was measured by the 3(4,5-dimethyl-2-thiazyl)-2,5-diphenyl- $2 \mathrm{H}$-tetrazolium bromide (MTT) assay [36]. The MTT assay is based on the cleavage of the tetrazolium salt MTT to a blue formazan dye by viable cells. LNCaP cells $\left(2 \times 10^{5} / \mathrm{mL}\right)$ were seeded $24 \mathrm{~h}$ before the experiments in a 96-well plate. Various concentrations of EEP-P $(25-50 \mu \mathrm{g} / \mathrm{mL})$ with or without TRAIL (100-200 ng/mL) were added to the cells for $24-48 \mathrm{~h}$. After this time, $20 \mu \mathrm{L}$ of MTT solution $(5 \mathrm{mg} / \mathrm{mL})$ was added to each well for $4 \mathrm{~h}$. The resulting blue formazan crystals were dissolved in DMSO. These reagents were purchased from Sigma Chemical Company (St. Louis, MO, USA). Controls included native cells and medium alone. Spectrophotometric absorbance was measured at $550 \mathrm{~nm}$ wavelength using Eon Microplate Spectrophotometer (BioTek, Winooski, VT, USA). The percent cytotoxicity was calculated by the following formula: percent cytotoxicity $($ cell death $)=(1-$ [absorbance of experimental wells/absorbance of control wells]) $\times 100 \%$.

2.7. Lactate Dehydrogenase Release Assay. Lactate dehydrogenase (LDH) is a stable cytosolic enzyme released upon membrane damage in necrotic cells. LDH activity was detected using a cytotoxicity assay kit (Roche Diagnostics GmbH, Mannheim, Germany) [37]. LNCaP cells were treated with EEP-P $(25-50 \mu \mathrm{g} / \mathrm{mL})$ with or without TRAIL (100$200 \mathrm{ng} / \mathrm{mL}$ ) for $24-48 \mathrm{~h}$. Supernatants were then removed from each sample for measurements of LDH. LDH released into the culture supernatants was detected with a coupled enzymatic assay that results in the conversion of a tetrazolium salt into a red formazan product. Spectrophotometric absorbance was measured at $490 \mathrm{~nm}$ wavelength using Eon Microplate Spectrophotometer (BioTek, Winooski, VT, USA). Maximal release of LDH was obtained after treating control cells with $1 \%$ Triton X-100 (Sigma Chemical Company) for $10 \mathrm{~min}$ at room temperature. The percentage of necrotic cells was expressed using the following formula: (sample value/maximal release) $\times 100 \%$.

2.8. Detection of Apoptosis by Flow Cytometry. Apoptosis was determined by flow cytometry using the Apoptest-FITC Kit with annexin V (Dako, Glostrup, Denmark). LNCaP cells $\left(2 \times 10^{5} / \mathrm{mL}\right)$ were seeded in 24 -well plates for $24 \mathrm{~h}$ prior to experimentation and then exposed to EEP-P (25$50 \mu \mathrm{g} / \mathrm{mL}$ ) and/or TRAIL (100-200 $\mathrm{ng} / \mathrm{mL}$ ) for $24-48 \mathrm{~h}$. Then the cells were washed twice with phosphate-buffered saline solution (PBS) and resuspended in $500 \mu \mathrm{L}$ of binding buffer. The cell suspension $(290 \mu \mathrm{L})$ was incubated with $5 \mu \mathrm{L}$ of annexin V-FITC and $5 \mu \mathrm{L}$ of propidium iodide for $10 \mathrm{~min}$ at room temperature in the dark. The population of annexin $\mathrm{V}$ positive cells was evaluated by flow cytometry (LSR II, Becton Dickinson Immunocytometry Systems, San Jose, CA, USA) [38].

\subsection{Detection of Apoptosis by Fluorescence Microscopy.} Apoptotic cells were quantified using the fluorescence microscopy method of the Apoptotic, and Necrotic, and Healthy Cells Quantification Kit from Biotium, Inc. (Hayward, CA, USA). LNCaP cells $\left(2 \times 10^{5} / \mathrm{mL}\right)$ were seeded in a 24 -well plate for $24 \mathrm{~h}$ before the experiments. EEP-P $(25-50 \mu \mathrm{g} / \mathrm{mL})$ and/or TRAIL $(100 \mathrm{ng} / \mathrm{mL})$ were added to the cells for $24-48 \mathrm{~h}$. After this time the cells were washed with PBS, and trypsinised. Next, the cells were centrifuged to discard the supernatant, washed with PBS and resuspended in binding buffer $(100 \mu \mathrm{L} /$ sample). A combination of $5 \mu \mathrm{L}$ of annexin V-FITC, $5 \mu \mathrm{L}$ of ethidium homodimer III, and $5 \mu \mathrm{L}$ of Hoechst 33342 solution was added to each tube. The samples were incubated at room temperature for $15 \mathrm{~min}$ in the dark, and then the cells were washed with binding buffer and placed on a glass slide. The stained cells were observed with an IX51 fluorescence inverted microscope (Olympus, Tokyo, Japan) using filter sets for FITC, TRITC, and DAPI [39]. The cells were counted, and the number of apoptotic cells was expressed as a percentage of the total number of cells.

2.10. Flow Cytometric Analysis of Death Receptor Expression. The cell surface expression of death receptors TRAIL-R1 (DR4) and TRAIL-R2 (DR5) was determined by flow cytometry (LSR II, Becton Dickinson Immunocytometry Systems, San Jose, CA, USA) [40]. LNCaP cells $\left(2 \times 10^{5} / \mathrm{mL}\right)$ were seeded in 24-well plates for $24 \mathrm{~h}$ and exposed to EEP-P $(25-50 \mu \mathrm{g} / \mathrm{mL})$ for $12-24 \mathrm{~h}$. The cells were then harvested using solution of trypsin and ethylenediaminetetraacetic acid (EDTA), washed twice in PBS, and resuspended in PBS containing $0.5 \%$ bovine serum albumin (BSA). LNCaP cells were incubated with $10 \mu \mathrm{L}$ phycoerythrin-conjugated antiTRAIL-R1 or anti-TRAIL-R2 monoclonal antibody (R\&D Systems, Minneapolis, MN, USA) at $4^{\circ} \mathrm{C}$ for $45 \mathrm{~min}$. After staining, the cells were washed with PBS and analyzed using flow cytometry. The control sample consisted of cells in a separate tube treated with phycoerythrin-labelled mouse $\operatorname{IgG}_{1}$ or mouse $\operatorname{IgG}_{2 B}$ (R\&D Systems). To show that the induction of apoptosis caused by the cotreatment of EEP and TRAIL is mediated through TRAIL-R2, the TRAIL-R2/Fc chimera protein (R\&D Systems) was used. TRAIL-R2/Fc acts as a dominant negative against endogenous TRAIL-R2/DR5 receptor.

2.11. The Statistical Analysis. The results are expressed as the mean \pm SD obtained from three independent experiments performed in quadruplicate $(n=12)$ or duplicate $(n=6)$. Statistical significance was evaluated using Student's $t$-test. $P$ values $<0.05$ were considered significant. 


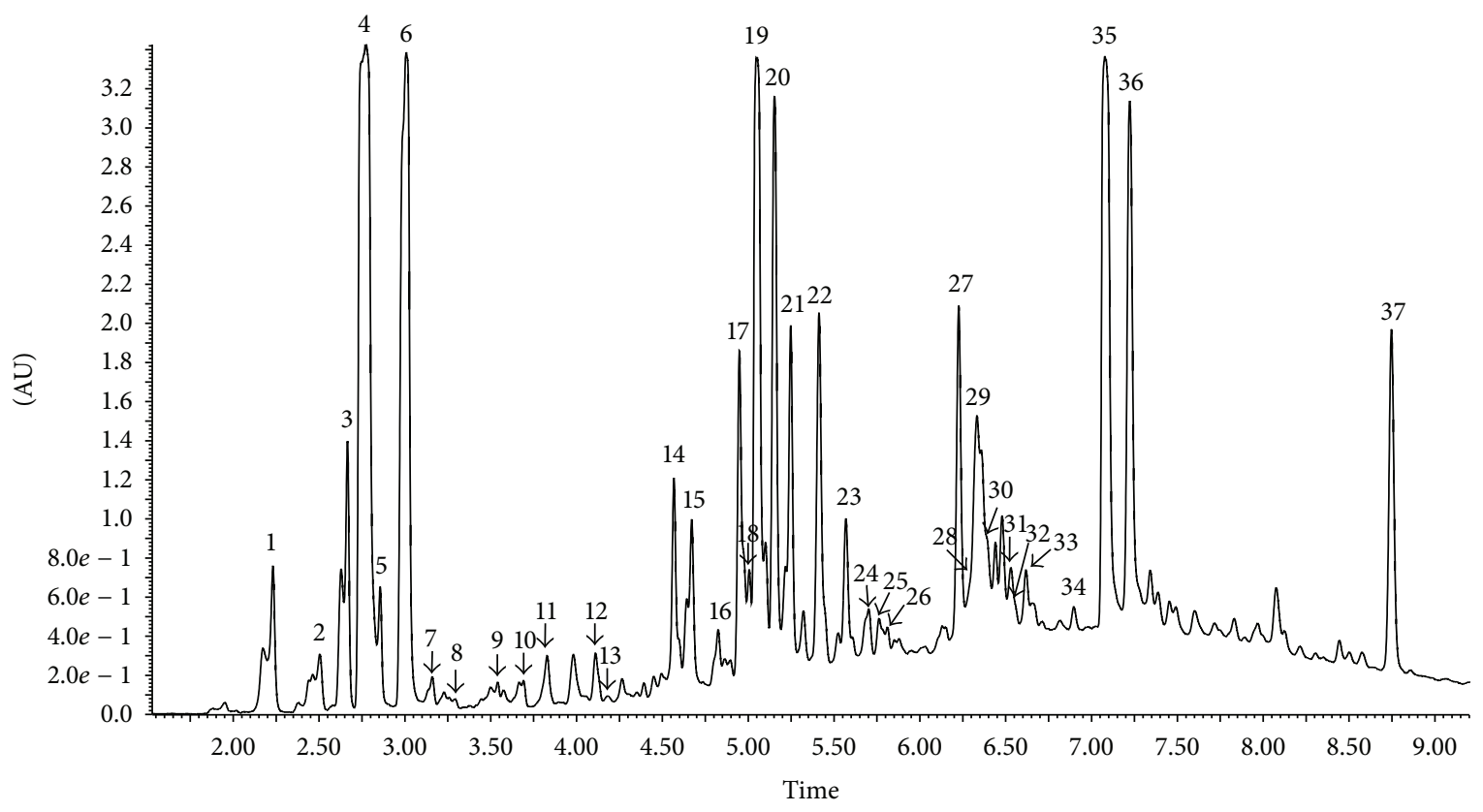

FIGURE 1: UPLC-DAD chromatogram $(290 \mathrm{~nm})$ of compounds of ethanol extract from Polish propolis.

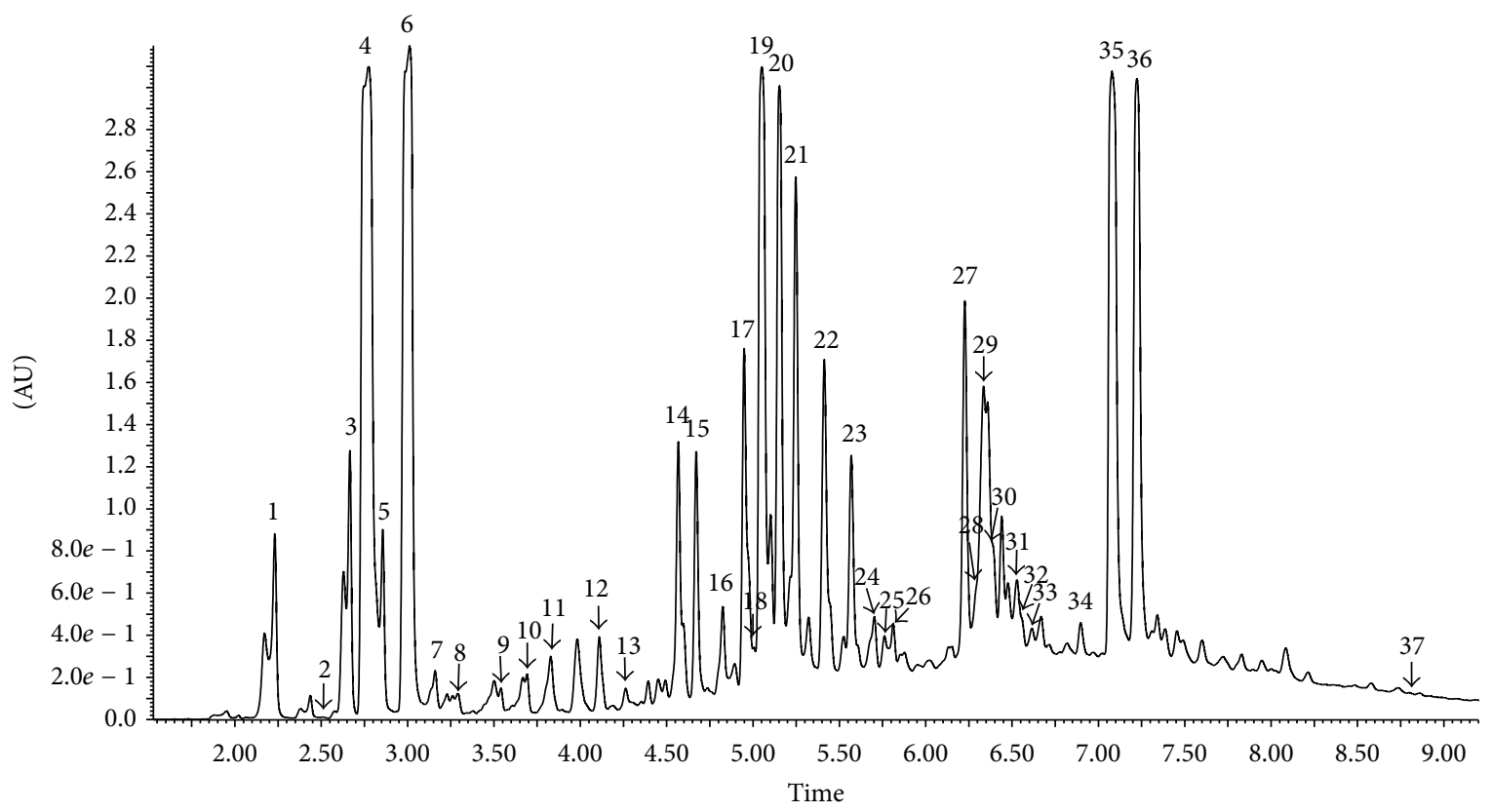

FIGURE 2: UPLC-DAD chromatogram $(325 \mathrm{~nm})$ of compounds of ethanol extract from Polish propolis.

\section{Results}

3.1. The Content and Characterization of Phenolic Compounds Identified in Extract of Polish Propolis. The chemical composition of extract of Polish propolis was determined using HPLC-DAD and UPLC-Q-TOF-MS methods. Qualitative analysis results obtained by LC-ESI/MS methods and quantitative analysis data evaluated by HPLC (quantified using DAD detection) are presented in Figures 1, 2, 3, and 4 and Table 1. A total of thirty-seven phenolic ingredients were found in tested propolis sample. Thirty-one compounds were identified by comparison of their UV and MS/MS spectra to standards and/or to the literature data, whereas the other six compounds remained unknown. Pinobanksin, chrysin, and methoxyflavanone, which were characterized by MS from their molecular ions at $m / z$ 271.0616, 253.0502, and 253.0806, respectively, are the major flavonoids identified in Polish propolis. Among the phenolic acids, prevailed $p$-coumaric acid $(m / z 163.0406$ and fragment at $m / z 119$ resulting from the loss of a COO group), ferulic acid $(m / z 193.0492$ and 


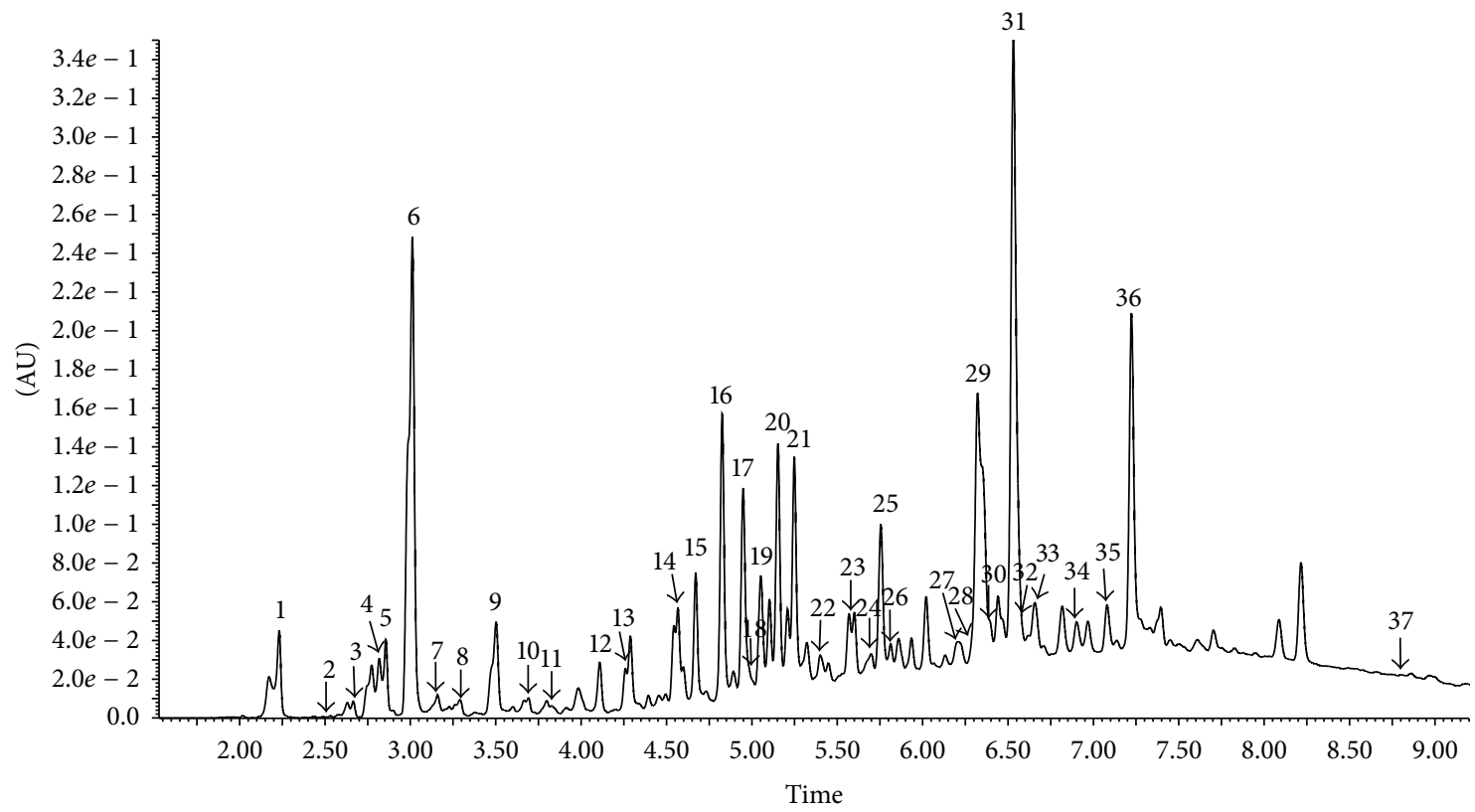

FIGURE 3: UPLC-DAD chromatogram $(370 \mathrm{~nm})$ of compounds of ethanol extract from Polish propolis.

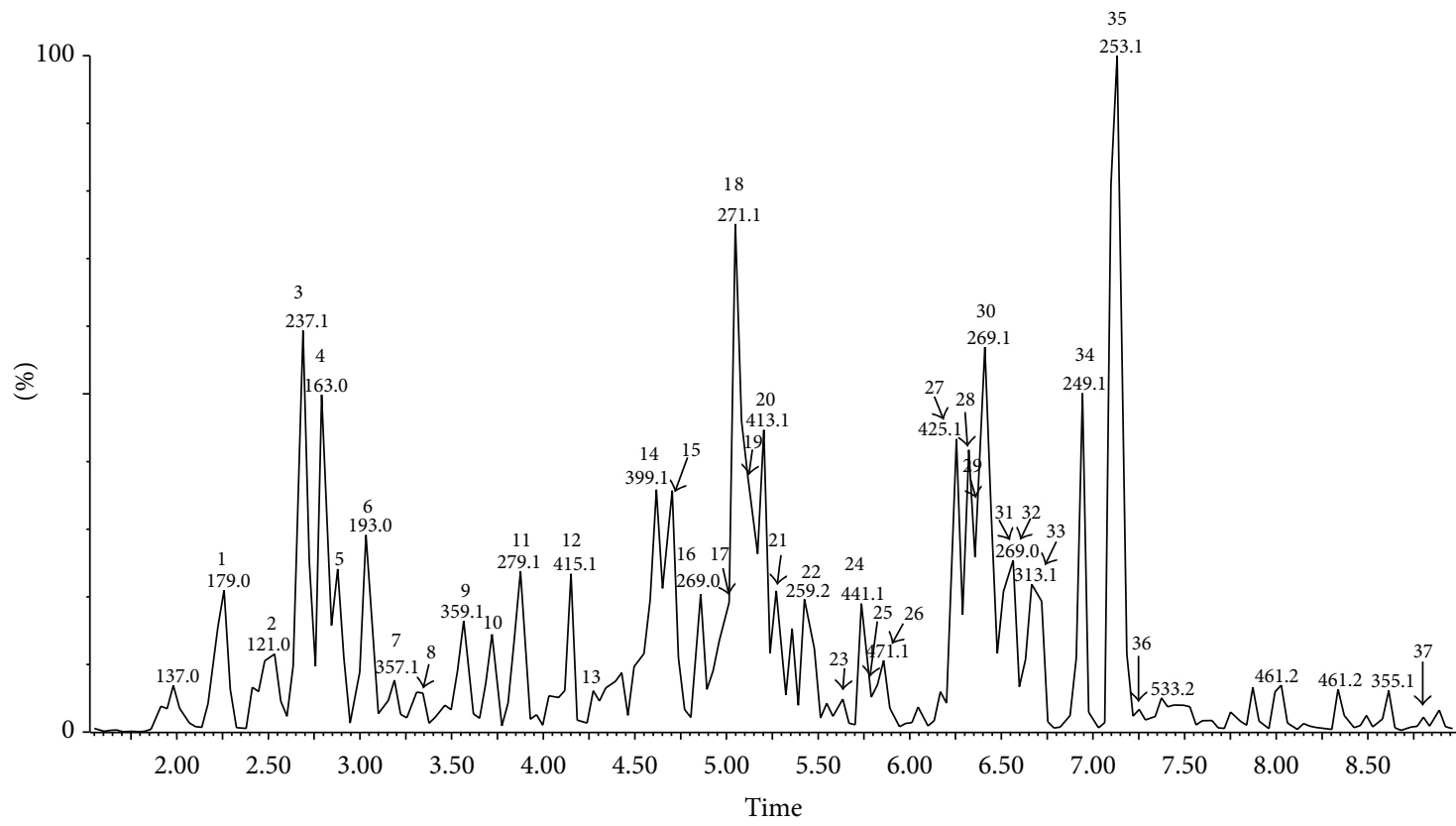

FIGURE 4: UPLC-ESI-MS (negative ion) chromatogram of main compounds of ethanol extract from Polish propolis.

fragments 149.0613 and 134,0375), caffeic acid $(\mathrm{m} / z 179.0349$ and fragments 161.0241 and 135.0440) and their derivatives (Table 1).

3.2. Anticancer Activity of EEP-P against LNCaP Cells. EEP-P induced cytotoxicity and apoptosis in a dose- and timedependent manner in LNCaP cells (Figure 5). The cytotoxic effect of $25-50 \mu \mathrm{g} / \mathrm{mL}$ EEP-P after a 24 -hour incubation was $5.2 \pm 1.4 \%$ to $11.7 \pm 1.1 \%$ cell death and after a 48 -hour incubation was $11.7 \pm 0.7 \%$ to $18.4 \pm 1.2 \%$ cell death. At the same concentrations EEP-P induced $6.9 \pm 0.8 \%-12.7 \pm$ $0.9 \%$ (24-hour incubation) and $14.6 \pm 0.7 \%-22.3 \pm 0.9 \%$ (48-hour incubation) apoptosis in LNCaP cells. The necrotic cell death percentage of LNCaP cells incubated with 25$50 \mu \mathrm{g} / \mathrm{mL}$ EEP-P for $24-48 \mathrm{~h}$ examined by Apoptest-FITC and $\mathrm{LDH}$ assay was near zero.

3.3. EEP-P Sensitizes LNCaP Cells to TRAIL-Induced Cytotoxicity and Apoptosis. The cytotoxic effect of $100 \mathrm{ng} / \mathrm{mL}$ TRAIL after a 24-hour incubation was $14.7 \pm 1.0 \%$ cell 
TABLE 1: The content $(\mathrm{mg} / \mathrm{g})$ and characterization of phenolic compounds of the ethanol extract of Polish propolis determined using their spectral characteristic in negative ions in LC-ESI/MS.

\begin{tabular}{|c|c|c|c|c|c|}
\hline Peak & $\begin{array}{l}\text { Retention time } t_{r} \\
(\mathrm{~min})\end{array}$ & $(\mathrm{M}-\mathrm{H})^{-}$ & MS/MS fragments & Compound name* & $\begin{array}{l}\text { Quantity }(\mathrm{mg} / \mathrm{g} \text { of } \\
\text { propolis) }\end{array}$ \\
\hline 1 & 2.26 & 179.0349 & $161.0241 / 135.0440$ & Caffeic acid ${ }^{\mathrm{a}}$ & 3.90 \\
\hline 2 & 2.53 & 121.0288 & 121.0288 & Benzoic acid ${ }^{\text {bc }}$ & $0.86^{\mathrm{d}}$ \\
\hline 3 & 2.69 & 237.0772 & $163.0406 / 145.0284 / 117.0342$ & $\mathrm{Ni}$ & $\operatorname{Tr}$ \\
\hline 4 & 2.79 & 163.0406 & 119.0488 & $p$-Coumaric acid ${ }^{\mathrm{a}}$ & 28.65 \\
\hline 5 & 2.88 & 267.0899 & $160.0154 / 133.0276$ & $\mathrm{Ni}$ & $\operatorname{Tr}$ \\
\hline 6 & 3.01 & 193.0492 & $178.0258 / 149.0613 / 134.0375$ & Ferulic acid ${ }^{\mathrm{a}}$ & 22.01 \\
\hline 7 & 3.18 & 357.0989 & $279.0655 / 147.0441$ & Ferulic acid derivative $^{c}$ & $0.59^{\mathrm{e}}$ \\
\hline 8 & 3.31 & 295.0815 & $161.0241 / 133.0299$ & Ferulic acid derivative $^{c}$ & $\operatorname{Tr}$ \\
\hline 9 & 3.57 & 359.1129 & $163.0380 / 145.0284 / 119.0510$ & Coumaric acid derivative $^{c}$ & $0.16^{\mathrm{g}}$ \\
\hline 10 & 3.72 & 389.1221 & $193.0492 / 134.0375 / 175.0399 / 160.0154$ & Ferulic acid derivative ${ }^{c}$ & $0.75^{\mathrm{e}}$ \\
\hline 11 & 3.88 & 279.086 & $145.0284 / 117.0342$ & $\mathrm{Ni}$ & $\operatorname{Tr}$ \\
\hline 12 & 4.15 & 415.1065 & $253.0730 / 179.0349 / 161.0241 / 135.0440$ & Caffeic acid derivative ${ }^{c}$ & $0.11^{\mathrm{f}}$ \\
\hline 13 & 4.27 & 355.1176 & $179.0349 / 163.0380 / 135.0440 / 119.0488$ & $\begin{array}{c}\text { Caffeic and coumaric acids } \\
\text { derivative }^{c}\end{array}$ & $\operatorname{Tr}$ \\
\hline 14 & 4.61 & 399.1051 & $253.0697 / 179.0349 / 163.0380 / 119.0488$ & $\begin{array}{c}\text { Coumaric and caffeic acids } \\
\text { derivative }^{c}\end{array}$ & $1.83^{\mathrm{g}}$ \\
\hline 15 & 4.70 & 429.1214 & $253.0697 / 193.0492 / 161.0241 / 134.0375$ & Ferulic acid derivative $^{c}$ & $2.12^{\mathrm{e}}$ \\
\hline 16 & 4.86 & 269.0469 & $151.0042 / 117.0342$ & Apigenin $^{\mathrm{a}}$ & 1.98 \\
\hline 17 & 4.96 & 383.1137 & & Coumaric acid derivative $^{c}$ & $3.97^{\mathrm{g}}$ \\
\hline 18 & 5.05 & 271.0616 & $253.0502 / 197.0596 / 161.0605 / 125.0241 / 107.0134$ & Pinobanksin ${ }^{\mathrm{a}}$ & 12.78 \\
\hline 19 & 5.10 & 383.1137 & $163.0406 / 119.0510$ & Coumaric acid derivative $^{c}$ & $22.87^{\mathrm{g}}$ \\
\hline 20 & 5.20 & 413.1240 & $193.0492 / 163.0380 / 134.0375 / 119.0488$ & $\begin{array}{l}\text { Coumaric and ferulic acids } \\
\text { derivative (metoxy-) }\end{array}$ & $13.44^{\mathrm{e}}$ \\
\hline 21 & 5.27 & 443.1320 & $193.0492 / 163.0380 / 134.0375 / 119.0488$ & $\begin{array}{c}\text { Coumaric and ferulic acids } \\
\text { derivative (dimetoxy- })^{c}\end{array}$ & $3.98^{\mathrm{e}}$ \\
\hline 22 & 5.44 & 259.1917 & 193.0492/163.0380/134.0375/119.0489 & Ferulic acid derivative ${ }^{c}$ & $2.02^{\mathrm{e}}$ \\
\hline 23 & 5.63 & 283.0594 & $193.0492 / 134.0375$ & Ferulic acid derivative ${ }^{c}$ & $0.3^{\mathrm{e}}$ \\
\hline 24 & 5.73 & 441.1179 & $179.0349 / 163.0406 / 135.0440 / 119.0388$ & $\begin{array}{c}\text { Caffeic and coumaric acids } \\
\text { derivative }^{c}\end{array}$ & $\operatorname{Tr}$ \\
\hline 25 & 5.79 & 315.0512 & 121.0288 & Rhamnetin $^{\mathrm{a}}$ & 0.49 \\
\hline 26 & 5.86 & 471.1305 & 297.1136/193.0492 & $\mathrm{Ni}$ & $\operatorname{Tr}$ \\
\hline 27 & 6.25 & 425.1242 & $163.0406 / 119.0510$ & Coumaric acid derivative $^{c}$ & 5.00 \\
\hline 28 & 6.32 & 247.0982 & $179.0349 / 163.0380 / 135.0440$ & $\begin{array}{c}\text { Coumaric and caffeic acids } \\
\text { derivative }^{c}\end{array}$ & $0.31^{\mathrm{f}}$ \\
\hline 29 & 6.35 & 253.0502 & 143.0510 & Chrysin $^{\mathrm{a}}$ & 6.56 \\
\hline 30 & 6.41 & 269.0804 & $178.0258 / 163.0380 / 134.0375 / 119.0488$ & $\mathrm{Ni}$ & - \\
\hline 31 & 6.56 & 269.0435 & $171.0446 / 151.0042 / 117.0342$ & Galangin $^{\mathrm{a}}$ & 0.47 \\
\hline 32 & 6.56 & 299.0572 & & Kaempferide ${ }^{\mathrm{g}}$ & $\operatorname{Tr}$ \\
\hline 33 & 6.66 & 313.0745 & 253.0502 & Pinobanksin-3-O-acetate ${ }^{\mathrm{b}}$ & $\operatorname{Tr}$ \\
\hline 34 & 6.94 & 249.1131 & 161.0241/133.0299 & $\mathrm{Ni}$ & - \\
\hline 35 & 7.13 & 253.0860 & $162.0308 / 151.0394 / 145.0284 / 117.0342$ & Methoxyflavanone $\mathrm{bc}^{\mathrm{bc}}$ & $20.50^{\mathrm{h}}$ \\
\hline 36 & 7.25 & 283.0973 & $163.0380 / 145.0653 / 119.0488$ & Coumaric acid derivative $^{c}$ & $10.49^{\mathrm{g}}$ \\
\hline 37 & 8.80 & 449.2537 & $361.2026 / 253.0502 / 121.0288$ & Benzoic acid derivative ${ }^{c}$ & $5.20^{\mathrm{d}}$ \\
\hline
\end{tabular}

Ni: not identified.

Tr: traces.

${ }^{*}$ a: confirmed by standard; b: confirmed by reference [41, 42]; c: confirmed by MS fragmentation.

${ }^{* *} \mathrm{~d}$ : expressed as cinnamic acid; e: expressed as ferulic acid; f: expressed as caffeic acid; g: expressed as p-coumaric acid; h: expressed as apigenin.

death and after a 48-hour incubation was $17.0 \pm 0.9 \%$ cell death. At the same concentration TRAIL induced $14.6 \pm$ $0.7 \%-17.0 \pm 0.8 \%$ apoptosis in a time-dependent manner in LNCaP cells. TRAIL concentrations higher than $100 \mathrm{ng} / \mathrm{mL}$ resulted in no significant increase in cytotoxic or apoptotic activity. These data confirmed that the LNCaP cell line is resistant to TRAIL-mediated apoptosis. Then the cytotoxic and apoptotic effects of EEP-P in combination with TRAIL were tested on LNCaP cells. After cotreatment of cancer cells with $25-50 \mu \mathrm{g} / \mathrm{mL}$ EEP-P and $100 \mathrm{ng} / \mathrm{mL}$ TRAIL for $24-48 \mathrm{~h}$ 


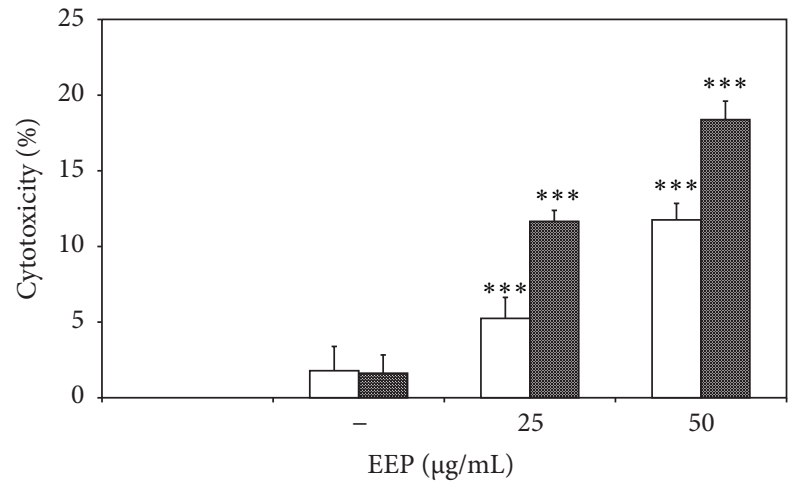

$\square 24 \mathrm{~h}$

圆 $48 \mathrm{~h}$

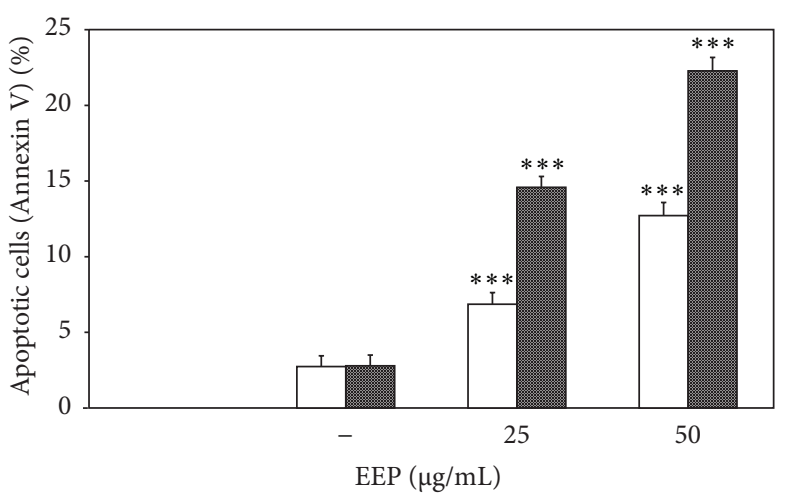

$\square 24 \mathrm{~h}$

$48 \mathrm{~h}$

(a)

(b)

FIGURE 5: Cytotoxic and apoptotic effects of EEP-P on LNCaP prostate cancer cells. Cells were incubated with 25-50 $\mu \mathrm{g} / \mathrm{mL}$ EEP-P for 24$48 \mathrm{~h}$. The values represent mean $\pm \mathrm{SD}$ of three independent experiments performed in quadruplicate $(n=12)$. (a) Cytotoxic activity of EEP-P against LNCaP cells. The percentage of cell death was measured using the MTT cytotoxicity assay $\left({ }^{* * *}=P<0.001\right.$ compared to control). (b) Apoptotic activity of EEP-P against LNCaP cells. Apoptotic cell death was detected by flow cytometry using annexin V-FITC staining $\left({ }^{* * *}=P<0.001\right.$ compared to control).

the cytotoxicity ranged $20.4 \pm 1.6 \%-66.9 \pm 0.7 \%$ in a dose- and time-dependent manner. The cytotoxicity measured by MTT assay is shown in Figure 6(a). EEP-P cooperated with TRAIL to induce apoptosis in prostate cancer cells. When cells were treated with the same concentrations of EEP and TRAIL for $24-48 \mathrm{~h}$, the percentage of apoptotic cells determined by annexin V-FITC staining using flow cytometry was elevated to $24.0 \pm 0.8-69.8 \pm 1.1 \%$ (Figure 6(b)). EEP-P sensitized the TRAIL-resistant LNCaP cells to TRAIL-mediated apoptosis. The annexin V-FITC staining, visualized by fluorescence microscopy, confirmed that EEP-P augments the apoptotic activity of TRAIL in LNCaP cells (Figure 6(c)). The necrotic cell death percentage of LNCaP cells incubated with EEP-P and/or TRAIL examined by Apoptest-FITC and LDH assay was near zero.

3.4. EEP-P Upregulates Expression of TRAIL-R2 Receptor in $L N C a P C e l l s$. The activation of death receptors on the cancer cell surface is critical for TRAIL-mediated apoptosis. Therefore, we analyzed the expression of death receptor TRAIL$\mathrm{R} 1$ and TRAIL-R2 in LNCaP cells after a 12-24 h treatment with $25-50 \mu \mathrm{g} / \mathrm{mL}$ EEP-P by flow cytometry (Figure 7). The high affinity death signaling TRAIL-R2 is more abundantly expressed in LNCaP cells than TRAIL-R1. Treatment with EEP-P significantly increased the expression of TRAIL-R2 but did not alter TRAIL-R1 expression on the cell surface. EEP-P induced TRAIL-R2 expression on LNCaP cells in a dose- and time-dependent manner. EEP-P sensitizes prostate cancer cells through TRAIL-R2 upregulation. To show that the induction of apoptosis caused by the cotreatment of EEP-P and TRAIL was mediated through TRAIL-R2, we used the TRAIL-R2/Fc chimera protein, which acts as a dominant negative against endogenous TRAIL-R2 receptor. The TRAIL-R2/Fc efficiently blocked apoptosis induced by cells EEP-P and TRAIL (Figure 8). These data indicate that the induction of TRAIL-R2 by EEP mediates the sensitization of LNCaP cells to TRAIL.

\section{Discussion}

Propolis extracts exert anticancer and chemopreventive properties by multiple mechanisms of action affecting apoptotic pathways in cancer cells. The role of propolis in host immune functions against tumor onset has become increasingly recognized in our understanding of the mechanisms of cancer prevention. EEP stimulates antitumor activity of TRAIL and enhances TRAIL-mediated immunity $[9,30]$. In our opinion, the immunomodulatory effect of propolis could be evoked by the targeting of TRAIL-induced apoptosis in cancer cells. We showed that TRAIL-resistant prostate cancer cells can be sensitized by Polish or Brazilian EEP and its phenolic components $[9,30]$. Because TRAIL-mediated apoptosis in LNCaP cells was augmented by EEP, we considered the possibility that propolis might influence the expression of DRs. There are two transmembrane agonistic receptors, TRAIL-R1 (DR4) and TRAIL-R2 (DR5), which bind ligand TRAIL by extracellular domains. DRs contain complete and functional intracellular death domains (DD) responsible for the activation of apoptotic pathway in cancer cells [21,23]. Ligation of TRAIL to DRs activates the extrinsic apoptotic pathway, also known as the death receptor pathway [17]. Expression of TRAIL-R1 and/or TRAIL-R2 in cancer cells plays a critical role in intensity and/or duration of death receptor-mediated signaling in response to death ligand [19]. The decreased level of DRs in cancer cell surface causes TRAIL resistance [27]. Recent studies using affinity assays and phage displays of DR-selective TRAIL variants have revealed that TRAIL-R2 may have a more prominent role than TRAIL-R1 in TRAIL-mediated apoptosis $[23,28]$. The flow cytometric analysis has shown significantly higher 


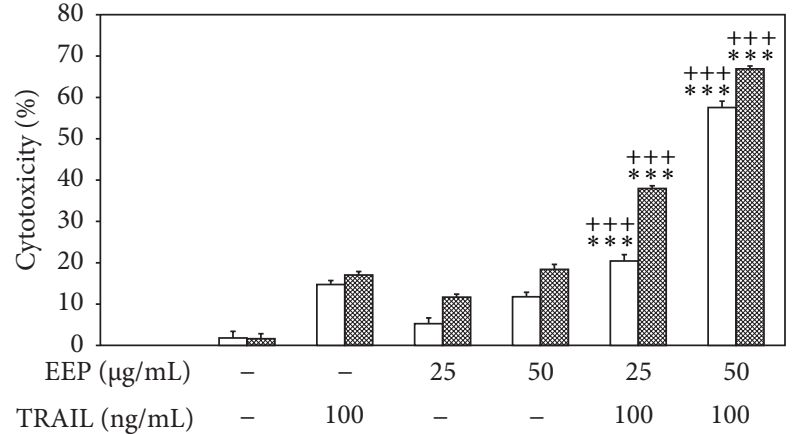

$\square 24 \mathrm{~h}$

网 $48 \mathrm{~h}$

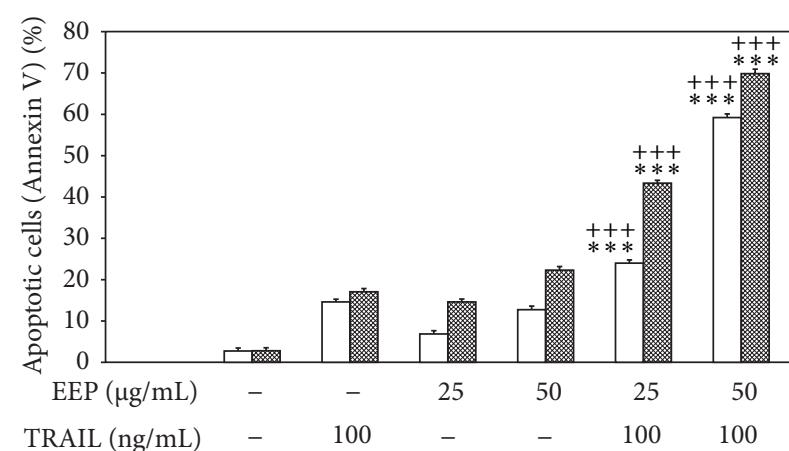

$\square 24 \mathrm{~h}$

网 $48 \mathrm{~h}$

(a)

(b)

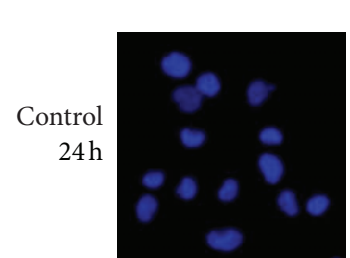

(A)

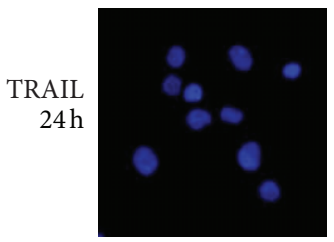

(D)

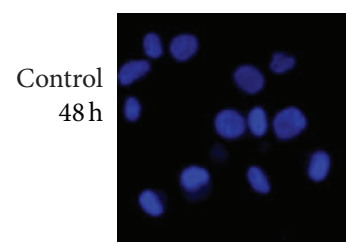

(G)

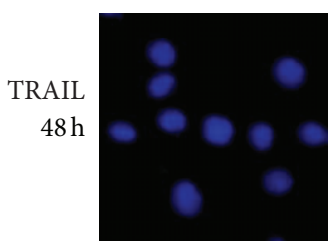

(J)
$\mathrm{EEP}-25 \mu \mathrm{g} / \mathrm{mL}$

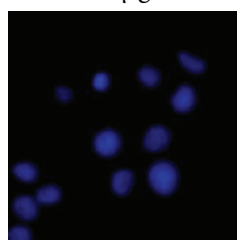

(B)

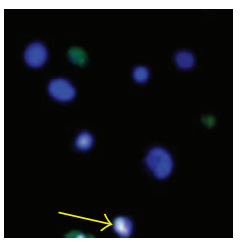

(E)

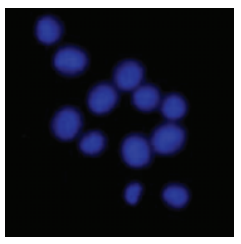

(H)

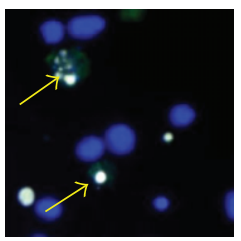

(K)

$\mathrm{EEP}-50 \mu \mathrm{g} / \mathrm{mL}$

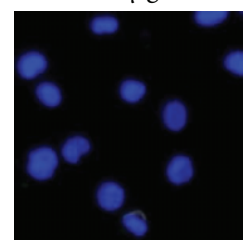

(C)

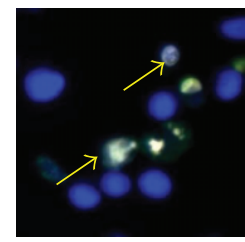

(F)

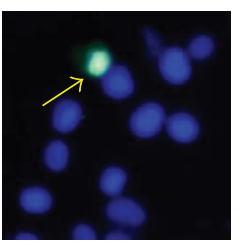

(I)

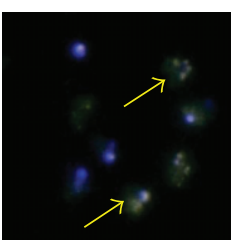

(L)

(c)

FIGURE 6: EEP-P sensitizes LNCaP prostate cancer cells to TRAIL-induced cytotoxicity and apoptosis. Cells were incubated with $25-50 \mu \mathrm{g} / \mathrm{mL}$ EEP-P and/or $100 \mathrm{ng} / \mathrm{mL}$ TRAIL for 24-48 h. The values represent mean \pm SD of three independent experiments performed in quadruplicate $(n=12)$. (a) Cytotoxic activity of EEP-P in combination with TRAIL against LNCaP cells. The percentage of cell death was measured using the MTT cytotoxicity assay $\left({ }^{* * *}=P<0.001\right.$ compared to EEP-P alone, ${ }^{+++}=P<0.001$ compared to TRAIL alone). (b) Apoptotic activity of EEP-P in combination with TRAIL against LNCaP cells. Apoptotic cell death was detected by flow cytometry using annexin V-FITC staining $\left({ }^{* * *}=P<0.001\right.$ compared to EEP-P alone, ${ }^{+++}=P<0.001$ compared to TRAIL alone). (c) Apoptotic activity of EEP-P in combination with TRAIL against LNCaP cells: (A) control cells, (B) cells incubated with $25 \mu \mathrm{g} / \mathrm{mL}$ EEP, (C) cells incubated with $50 \mu \mathrm{g} / \mathrm{mL}$ EEP, (D) cells incubated with $100 \mathrm{ng} / \mathrm{mL}$ TRAIL, (E) cells incubated with $25 \mu \mathrm{g} / \mathrm{mL}$ EEP and $100 \mathrm{ng} / \mathrm{mL}$ TRAIL, (F) cells incubated with $50 \mu \mathrm{g} / \mathrm{mL}$ EEP and $100 \mathrm{ng} / \mathrm{mL}$ TRAIL for $24 \mathrm{~h},(\mathrm{G})$ control cells, (H) cells incubated with $25 \mu \mathrm{g} / \mathrm{mL}$ EEP, (I) cells incubated with $50 \mu \mathrm{g} / \mathrm{mL}$ EEP, (J) cells incubated with $100 \mathrm{ng} / \mathrm{mL}$ TRAIL, (K) cells incubated with $25 \mu \mathrm{g} / \mathrm{mL}$ EEP and $100 \mathrm{ng} / \mathrm{mL}$ TRAIL, and (L) cells incubated with $50 \mu \mathrm{g} / \mathrm{mL}$ EEP and $100 \mathrm{ng} / \mathrm{mL}$ TRAIL for $48 \mathrm{~h}$. Apoptotic cell death was detected and visualized by fluorescence microscopy using annexin V-FITC staining. Healthy cells (stained with Hoechst 33342) emitted blue fluorescence and apoptotic cells (stained with Hoechst 33342 and annexin V-FITC) emitted green and blue fluorescence (indicated by arrows). 
TRAIL-R1

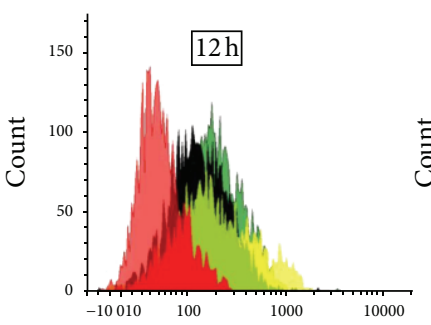

Trail R1 PE-A

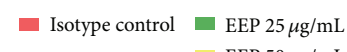

- Control EEP $50 \mu \mathrm{g} / \mathrm{mL}$

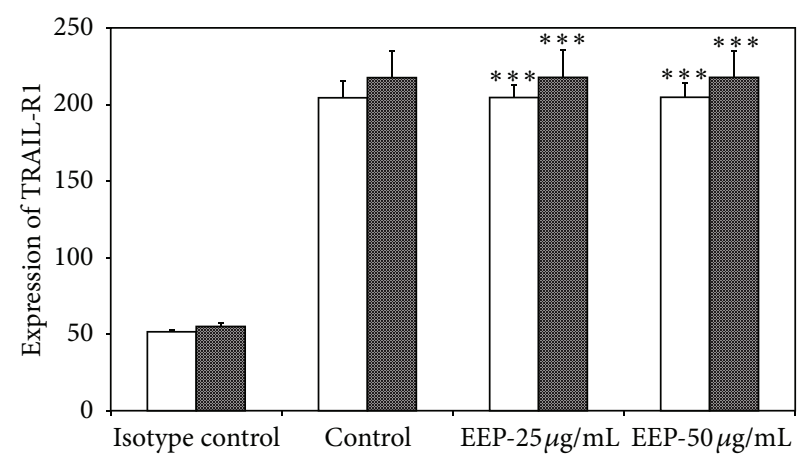

$\square 12 \mathrm{~h}$

$24 \mathrm{~h}$

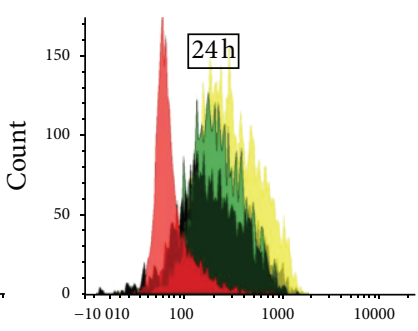

Trail R1 PE-A
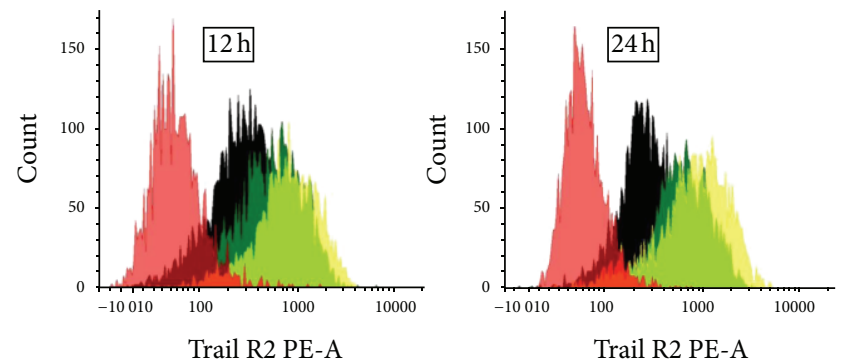

Isotype control $\square \mathrm{EEP} 25 \mu \mathrm{g} / \mathrm{mL}$

- Control $\quad$ EEP $50 \mu \mathrm{g} / \mathrm{mL}$

- Isotype control $\quad \mathrm{EEP} 25 \mu \mathrm{g} / \mathrm{mL}$

- Control $\quad$ EEP $50 \mu \mathrm{g} / \mathrm{mL}$

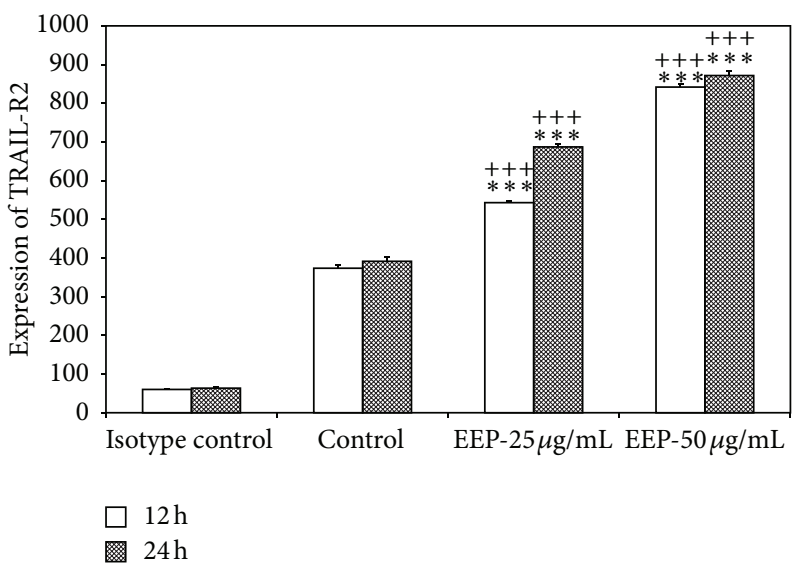

(b)

FIGURE 7: Effects of EEP-P on death receptor expression in LNCaP prostate cancer cells. Cells were incubated with $25-50 \mu \mathrm{g} / \mathrm{mL}$ for $12-24 \mathrm{~h}$. (a) TRAIL-R1 and (b) TRAIL-R2 expression on LNCaP cells treated with EEP-P measured by flow cytometry. The values represent mean \pm $\mathrm{SD}$ of three independent experiments performed in quadruplicate $(n=12)$ shown as the average mean fluorescence $\left({ }^{* * *}=P<0.001 \mathrm{EEP}-\mathrm{P}\right.$ compared to isotype control, ${ }^{+++}=P<0.001$ EEP-P compared to control) and histograms.

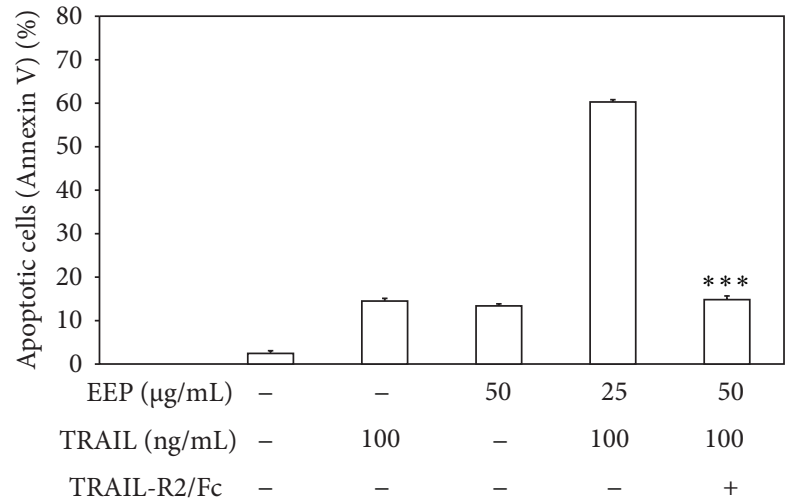

FIGURE 8: TRAIL-R2/Fc chimera block apoptosis induced by combination of EEP-P and TRAIL in LNCaP prostate cancer cells. Cells were incubated with $50 \mu \mathrm{g} / \mathrm{mL}$ EEP-P and/or $100 \mathrm{ng} / \mathrm{mL}$ TRAIL with or without $1 \mu \mathrm{g} / \mathrm{mL}$ TRAIL-R2/Fc chimera proteins for $24 \mathrm{~h}$. Apoptotic cell death was detected by annexin V-FITC staining using flow cytometry. The values represent mean \pm SD of three independent experiments performed in duplicate $(n=6)\left({ }^{* * *}=\right.$ $P<0.001$ compared to combination EEP-P+TRAIL). expression of TRAIL-R2 in LNCaP cells in comparison to TRAIL-R1. To explain the mechanism underlying the synergistic induction of apoptosis by propolis extract in LNCaP cells, we examined the effect of EEP-P on DRs expression. EEP-P markedly increased TRAIL-R2 protein level in LNCaP cells. Our previous findings demonstrated that the upregulation of TRAIL-R2 by Brazilian green propolis extract enhances TRAL-induced apoptosis in LNCaP cells [30].

Propolis significantly augmented the anticancer activity of TRAIL due to its phenolics [29]. It has been suggested that influence of TRAIL-R2 or TRAIL-R1 is a common response to treatment of cancer cells with compounds identified in propolis such as chrysin, apigenin, kaempferol, quercetin, or artepillin C. Chrysin and apigenin reverse TRAIL resistance in MDA-MB-231 breast cancer cells, HT-29 colon cancer cells, HepG2 hepatocellular cancer cells, SK-MEL-37 melanoma cells, and Capan-1 pancreatic cancer cells via increased expression of TRAIL-R2 and decreased expression of FLIP [43]. Apigenin augments TRAIL-induced apoptosis in Jurkat leukemia cells, DU145 prostate cancer cells, and DLD-1 colon cancer cells through upregulation of TRAIL-R2 and 
activation of Bid and caspase-8, -10, -9, -3 [44]. Quercetin strongly cooperates with TRAIL to trigger apoptosis in HepG2, SK-Hep, SNU-387, SNU-423, SNU-449, and SNU475 hepatocellular cancer cells by increased expression of TRAIL-R2 and decreased expression of FLIP, in HT-29, SW620 , and Caco- 2 colon cancer cells by upregulation of TRAIL$\mathrm{R} 1$ and TRAIL-R2, induction of Bid and caspase- 3 cleavage, and release of cytochrome $c$ to the cytosol, in DU145 prostate cancer cells by upregulation of TRAIL-R2 and activation of caspase-9 and -3, in H460, H2009, H1299, and A549 lung cancer cells by increase of TRAIL-R2 expression, activation of caspase- 8 and -3 , and inactivation of Akt and survivin [45-48]. Induction of TRAIL-R1 and TRAIL-R2 expression and caspase-8, -10, -9, -3 activation in SW-480 colon cancer cells by kaempferol are sufficient to restore TRAIL sensitivity [49]. Artepillin C overcomes TRAIL-resistance in LNCaP prostate cancer cells by upregulation of TRAIL-R2, activation of caspase- 8 and caspase-3, and the disruption of MMP [50].

Phenolic components contribute to overall cancer preventive and antitumor properties of propolis $[9,29,30]$. The tested sample of Polish propolis was rich in pinobanksin, chrysin, methoxyflavanone, $p$-coumaric acid, ferulic acid, caffeic acid, and their derivatives.

The TRAIL-induced apoptotic pathway in cancer cells may be a target for the chemopreventive activity of propolis and its phenolic ingredients. In this report, we demonstrated for the first time the mechanism by which EEP-P affects TRAIL-mediated apoptosis. EEP-P reverses TRAILresistance in LNCaP cells through upregulation of TRAIL-R2. These findings suggest that EEP-P supports TRAIL-mediated immunochemoprevention in prostate cancer cells.

\section{Conclusion}

Targeting TRAIL-induced apoptotic pathway in prostate cancer cells by EEP could be one of the mechanisms responsible for chemopreventive activity of propolis. Extract of Polish propolis sensitizes prostate cancer cells to TRAIL-mediated apoptosis through upregulation of TRAIL-R2 expression.

\section{Conflict of Interests}

No conflict of interests was declared in relation to this paper.

\section{Acknowledgment}

This work was supported by a research Grant KNW-1063/P/2/0 from the Medical University of Silesia in Katowice (Poland).

\section{References}

[1] D. A. Kennedy, J. Hart, and D. Seely, "Cost effectiveness of natural health products: a systematic review of randomized clinical trials," Evidence-Based Complementary and Alternative Medicine, vol. 6, no. 3, pp. 297-304, 2009.

[2] L. Gibellini, M. Pinti, M. Nasi et al., "Quercetin and cancer chemoprevention," Evidence-Based Complementary and Alternative Medicine, vol. 2011, Article ID 591356, 15 pages, 2011.
[3] S. J. Klempner and G. Bubley, "Complementary and alternative medicines in prostate cancer: from bench to bedside," The Oncologist, vol. 17, no. 6, pp. 830-837, 2012.

[4] E. Szliszka and W. Krol, "Soy isoflavones augment the effect of TRAIL-mediated apoptotic death in prostate cancer cells," Oncology Reports, vol. 26, no. 3, pp. 533-541, 2011.

[5] S. Cimino, G. Sortino, V. Favilla et al., "Polyphenols: key issues involved in chemoprevention of prostate cancer," Oxidative Medicine and Cellular Longevity, vol. 2012, Article ID 632959, 8 pages, 2012.

[6] E. W. Teixeira, D. Message, G. Negri, A. Salatino, and P. C. Stringheta, "Seasonal variation, chemical composition and antioxidant activity of brazilian propolis samples," EvidenceBased Complementary and Alternative Medicine, vol. 7, no. 3, pp. 307-315, 2010.

[7] G. C. Franchi, C. S. Moraes, V. C. Toreti, A. Daugsch, A. E. Nowill, and Y. K. Park, "Comparison of effects of the ethanolic extracts of brazilian propolis on human leukemic cells as assessed with the MTT assay," Evidence-Based Complementary and Alternative Medicine, vol. 2012, Article ID 918956, 6 pages, 2012.

[8] W. Maciejewicz, M. Daniewski, K. Bal, and W. Markowski, "GC-MS identification of the flavonoid aglycones isolated from propolis," Chromatographia, vol. 53, no. 5-6, pp. 343-346, 2001.

[9] E. Szliszka, Z. P. Czuba, J. Bronikowska, A. Mertas, A. Paradysz, and W. Krol, "Ethanolic extract of propolis augments TRAILinduced apoptotic death in prostate cancer cells," EvidenceBased Complementary and Alternative Medicine, vol. 2011, Article ID 535172, 11 pages, 2011.

[10] B. Kędzia, "Chemical composition of Polish propolis: the initial period of investigations," Postępy Fitoterapii, vol. 1, pp. 39-44, 2009.

[11] B. Kędzia, "Chemical composition of Polish propolis: new studies," Postępy Fitoterapii, vol. 2, pp. 122-128, 2009.

[12] N. Oršolić, A. B. Šaranović, and I. Bašić, "Direct and indirect mechanism(s) of antitumour activity of propolis and its polyphenolic compounds," Planta Medica, vol. 72, no. 1, pp. 2027, 2006.

[13] D. Sawicka, H. Car, M. H. Borawska, and J. Nikliński, "The anticancer activity of propolis," Folia Histochemica et Cytobiologica, vol. 50, no. 1, pp. 25-37, 2012.

[14] H. Li, A. Kapur, J. X. Yang et al., "Antiproliferation of human prostate cancer cells by ethanolic extracts of Brazilian propolis and its botanical origin," International Journal of Oncology, vol. 31, no. 3, pp. 601-606, 2007.

[15] A. Ashkenazi, R. C. Pai, S. Fong et al., "Safety and antitumor activity of recombinant soluble Apo2 ligand," Journal of Clinical Investigation, vol. 104, no. 2, pp. 155-162, 1999.

[16] A. Almasan and A. Ashkenazi, "Apo2L/TRAIL: apoptosis signaling, biology, and potential for cancer therapy," Cytokine and Growth Factor Reviews, vol. 14, no. 3-4, pp. 337-348, 2003.

[17] J. Y. Lee, S. Huerta-Yepez, M. Vega, S. Baritaki, D. A. Spandidos, and B. Bonavida, "The NO TRAIL to YES TRAIL in cancer therapy (review)," International Journal of Oncology, vol. 31, no. 4, pp. 685-691, 2007.

[18] J. Bronikowska, E. Szliszka, D. Jaworska, Z. P. Czuba, and W. Krol, "The coumarin psoralidin enhances anticancer effect of tumor necrosis factor-related apoptosis-inducing ligand (TRAIL)," Molecules, vol. 17, no. 6, pp. 6449-6464, 2012.

[19] P. A. Holoch and T. S. Griffith, "TNF-related apoptosis-inducing ligand (TRAIL): a new path to anti-cancer therapies," European Journal of Pharmacology, vol. 625, no. 1-3, pp. 63-72, 2009. 
[20] G. Pan, K. O'Rourke, A. M. Chinnaiyan et al., “The receptor for the cytotoxic ligand TRAIL," Science, vol. 276, no. 5309, pp. 111113, 1997.

[21] E. Szliszka, B. Mazur, G. Zdowicz, Z. P. Czuba, and W. Król, "TRAIL-induced apoptosis and expression of death receptor TRAIL-R1 and TRAIL-R2 in bladder cancer cells," Folia Histochemica et Cytobiologica, vol. 47, no. 4, pp. 579-585, 2009.

[22] S. A. Marsters, R. A. Pitti, J. P. Sheridan, and A. Ashkenazi, "Control of apoptosis signaling by Apo 2 ligand," Recent Progress in Hormone Research, vol. 54, pp. 225-234, 1999.

[23] J. Abdulghani and W. S. El-Deiry, "TRAIL receptor signaling and therapeutics," Expert Opinion on Therapeutic Targets, vol. 14, no. 10, pp. 1091-1108, 2010.

[24] S. Wang and W. S. El-Deiry, "TRAIL and apoptosis induction by TNF-family death receptors," Oncogene, vol. 22, no. 53, pp. 8628-8633, 2003.

[25] G. Mellier, S. Huang, K. Shenoy, and S. Pervaiz, "TRAILing death in cancer," Molecular Aspects of Medicine, vol. 31, no. 1, pp. 93-112, 2010.

[26] L. Zhang and B. Fang, "Mechanisms of resistance to TRAILinduced apoptosis in cancer," Cancer Gene Therapy, vol. 12, no. 3, pp. 228-237, 2005.

[27] A. Thorburn, K. Behbakht, and H. Ford, "TRAIL receptortargeted therapeutics: resistance mechanisms and strategies to avoid them," Drug Resistance Updates, vol. 11, no. 1-2, pp. 17-24, 2008.

[28] S. Bernardi, P. Secchiero, and G. Zauli, "State of art and recent developments of anti-cancer strategies based on TRAIL," Recent Patents on Anti-Cancer Drug Discovery, vol. 7, no. 2, pp. 207-217, 2012.

[29] E. Szliszka and W. Krol, "Polyphenols isolated from propolis augment TRAIL-induced apoptosis in cancer cells," EvidenceBased Complementary and Alternative Medicine, vol. 2013, Article ID 731940, 10 pages, 2013.

[30] E. Szliszka, G. Zydowicz, B. Janoszka, C. Dobosz, G. KowalczykZiomek, and W. Krol, "Ethanolic extract of Brazilian green propolis sensitizes prostate cancer cells to TRAIL-induced apoptosis," International Journal of Oncology, vol. 38, no. 4, pp. 941-953, 2011.

[31] H. Walczak, M. A. Degli-Esposti, R. S. Johnson et al., “TRAILR2: a novel apoptosis-mediating receptor for TRAIL," EMBO Journal, vol. 16, no. 17, pp. 5386-5397, 1997.

[32] J. Bodmer, N. Holler, S. Reynard et al., "TRAIL receptor-2 signals apoptosis through FADD and caspase-8," Nature Cell Biology, vol. 2, no. 4, pp. 241-243, 2000.

[33] S. I. Falcao, N. Vale, P. Gomes et al., "Phenolic profiling of Portuguese propolis by LC-MS spectrometry: uncommon propolis rich in flavonoid glycosides," Phytochemical Analysis, vol. 24, no. 4, pp. 309-318, 2013.

[34] D. Wojnicz, A. Z. Kucharska, A. Sokół-Łętowska, M. Kicia, and D. Tichaczek-Goska, "Medicinal plants extracts affect virulence factors expression and biofilm formation by the uropathogenic Escherichia coli," Urological Research, vol. 40, no. 6, pp. 683-697, 2012.

[35] E. Szliszka, J. Bronikowska, A. Majcher, J. Miszkiewicz, and W. Krol, "Enhanced sensitivity of hormone-refractory prostate cancer cells to tumour necrosis factor-related apoptosisinducing ligand (TRAIL) mediated cytotoxicity by taxanes," Central European Journal of Urology, vol. 62, no. 1, pp. 29-34, 2009.
[36] E. Szliszka, Z. P. Czuba, L. Sędek, A. Paradysz, and W. Król, "Enhanced TRAIL-mediated apoptosis in prostate cancer cells by the bioactive compounds neobavaisoflavone and psoralidin isolated from Psoralea corylifolia," Pharmacological Reports, vol. 63, no. 1, pp. 139-148, 2011.

[37] E. Szliszka, J. Gebka, J. Bronikowska, and W. Krol, "Dietary flavones enhance the effect of tumor necrosis factor-related apoptosis-inducing ligand (TRAIL) on bladder cancer cells," Central European Journal of Urology, vol. 63, no. 3, pp. 138-143, 2010.

[38] E. Szliszka, Z. P. Czuba, A. Kawczyk-Krupka, K. Sieron-Stoltny, A. Sieron, and W. Krol, "Chlorin-based photodynamic therapy enhances the effect of tumor necrosis factor-related apoptosisinducing ligand (TRAIL) in bladder cancer cells," Medical Science Monitor, vol. 18, no. 1, pp. BR47-BR53, 2012.

[39] E. Szliszka, K. J. Helewski, E. Mizgala, and W. Krol, "The dietary flavonol fisetin enhances the apoptosis-inducing potential of TRAIL in prostate cancer cells," International Journal of Oncology, vol. 39, no. 4, pp. 771-779, 2011.

[40] E. Szliszka, Z. P. Czuba, A. Mertas, A. Paradysz, and W. Krol, "The dietary isoflavone biochanin-a sensitizes prostate cancer cells to TRAIL-induced apoptosis," Urologic Oncology: Seminars and Original Investigations, vol. 31, no. 3, pp. 331-342, 2013.

[41] E. S. Chernetsova, M. Bromirski, O. Scheibner, and G. E. Morlock, "DART-Orbitrap MS: a novel mass spectrometric approach for the identification of phenolic compounds in propolis," Analytical and Bioanalytical Chemistry, vol. 403, no. 10, pp. 2859-2867, 2012.

[42] S. Keckes, U. Gasic, T. Cirkovic-Velickovic, D. MilojkovicOpsenica, M. Natic, and Z. Tesic, "The determination of phenolic profiles of Serbian unifloral honeys using ultra-highperformance liquid chromatography/high resolution accurate mass spectrometry," Food Chemistry, vol. 138, no. 1, pp. 32-40, 2013.

[43] J. Ding, G. Polier, R. Köhler, M. Giaisi, P. H. Krammer, and M. Li-Weber, "Wogonin and related natural flavones overcome tumor necrosis factor-related apoptosis-inducing ligand (TRAIL) protein resistance of tumors by down-regulation of c-FLIP protein and up-regulation of TRAIL receptor 2 expression," The Journal of Biological Chemistry, vol. 287, no. 1, pp. 641649, 2012.

[44] M. Horinaka, T. Yoshida, T. Shiraishi, S. Nakata, M. Wakada, and T. Sakai, "The dietary flavonoid apigenin sensitizes malignant tumor cells to tumor necrosis factor-related apoptosisinducing ligand," Molecular Cancer Therapeutics, vol. 5, no. 4, pp. 945-951, 2006.

[45] W. Chen, X. Wang, J. Zhuang, L. Zhang, and Y. Lin, "Induction of death receptor 5 and suppression of survivin contribute to sensitization of TRAIL-induced cytotoxicity by quercetin in non-small cell lung cancer cells," Carcinogenesis, vol. 28, no. 10, pp. 2114-2121, 2007.

[46] F. H. Psahoulia, K. G. Drosopoulos, L. Doubravska, L. Andera, and A. Pintzas, "Quercetin enhances TRAIL-mediated apoptosis in colon cancer cells by inducing the accumulation of death receptors in lipid rafts," Molecular Cancer Therapeutics, vol. 6, no. 9, pp. 2591-2599, 2007.

[47] J. Y. Kim, E. H. Kim, S. S. Park, J. H. Lim, T. K. Kwon, and K. S. Choi, "Quercetin sensitizes human hepatoma cells to TRAIL-induced apoptosis via Spl-mediated DR5 up-regulation and proteasome-mediated c-FLIPS down-regulation," Journal of Cellular Biochemistry, vol. 105, no. 6, pp. 1386-1398, 2008. 
[48] Y. H. Jung, J. Heo, Y. J. Lee, T. K. Kwon, and Y. H. Kim, "Quercetin enhances TRAIL-induced apoptosis in prostate cancer cells via increased protein stability of death receptor 5," Life Sciences, vol. 86, no. 9-10, pp. 351-357, 2010.

[49] T. Yoshida, M. Konishi, M. Horinaka et al., "Kaempferol sensitizes colon cancer cells to TRAIL-induced apoptosis," Biochemical and Biophysical Research Communications, vol. 375, no. 1, pp. 129-133, 2008.

[50] E. Szliszka, G. Zydowicz, E. Mizgala, and W. Krol, "Artepillin C, (3,5-diprenyl-4-hydroxycinnamic acid) sensitizes prostate cancer LNCaP cells to TRAIL-induced apoptosis," International Journal of Oncology, vol. 41, pp. 818-828, 2012. 


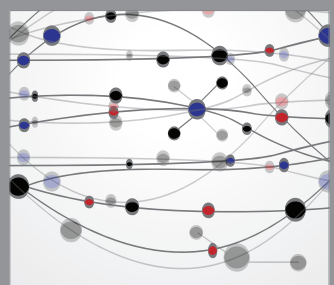

The Scientific World Journal
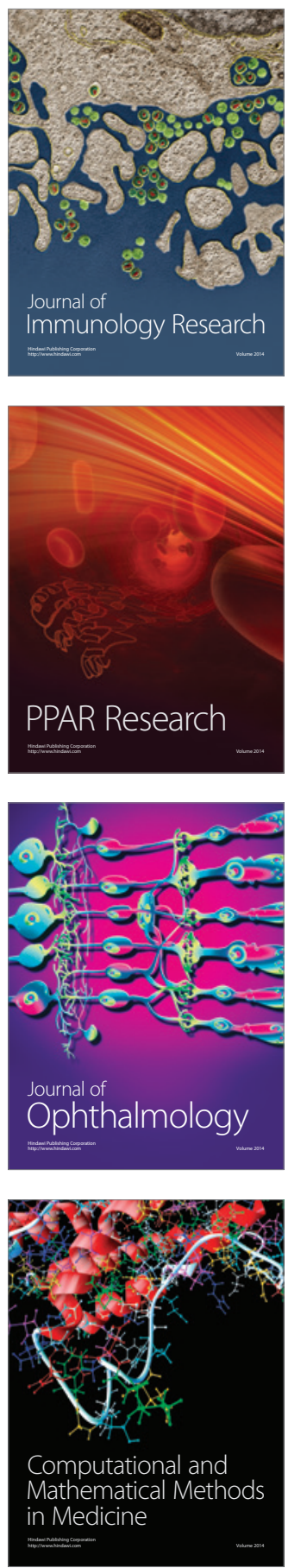

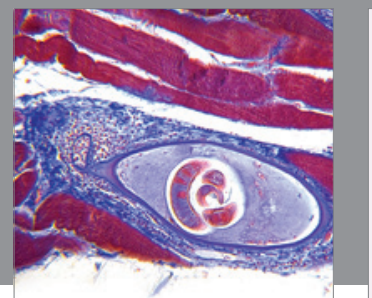

Gastroenterology

Research and Practice
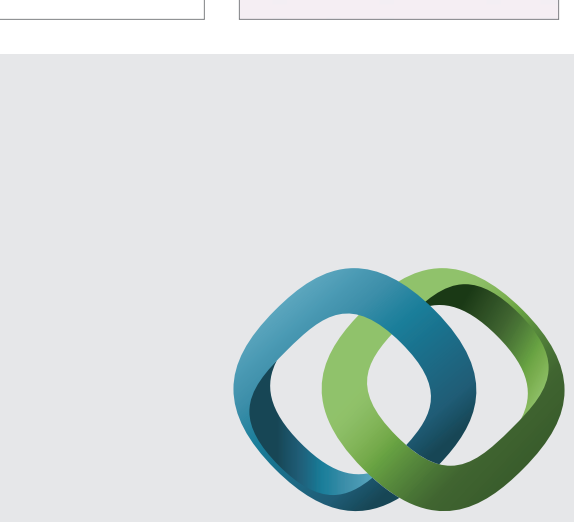

\section{Hindawi}

Submit your manuscripts at

http://www.hindawi.com
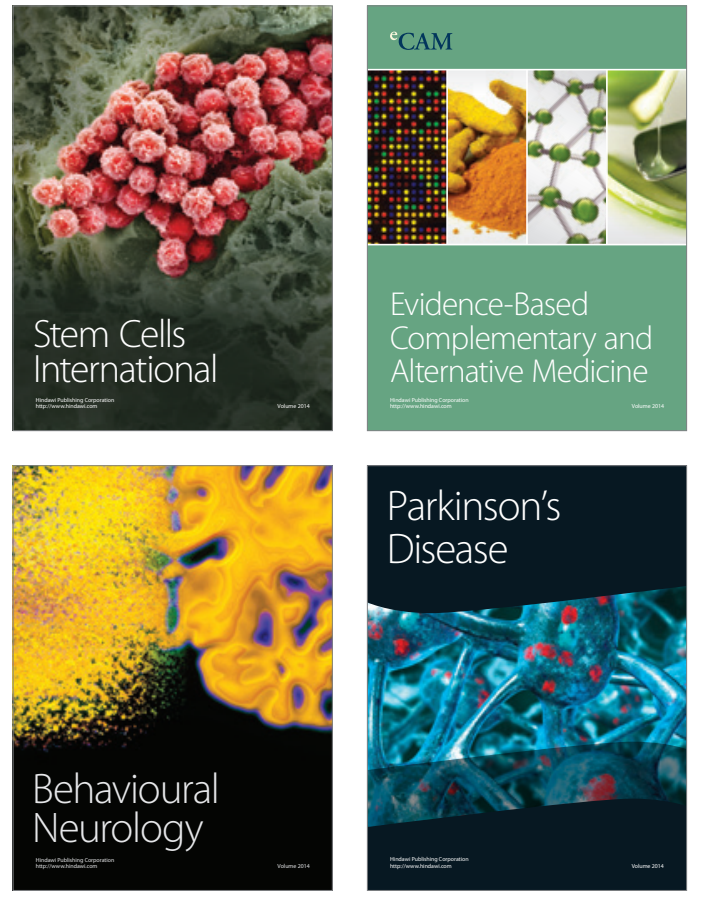
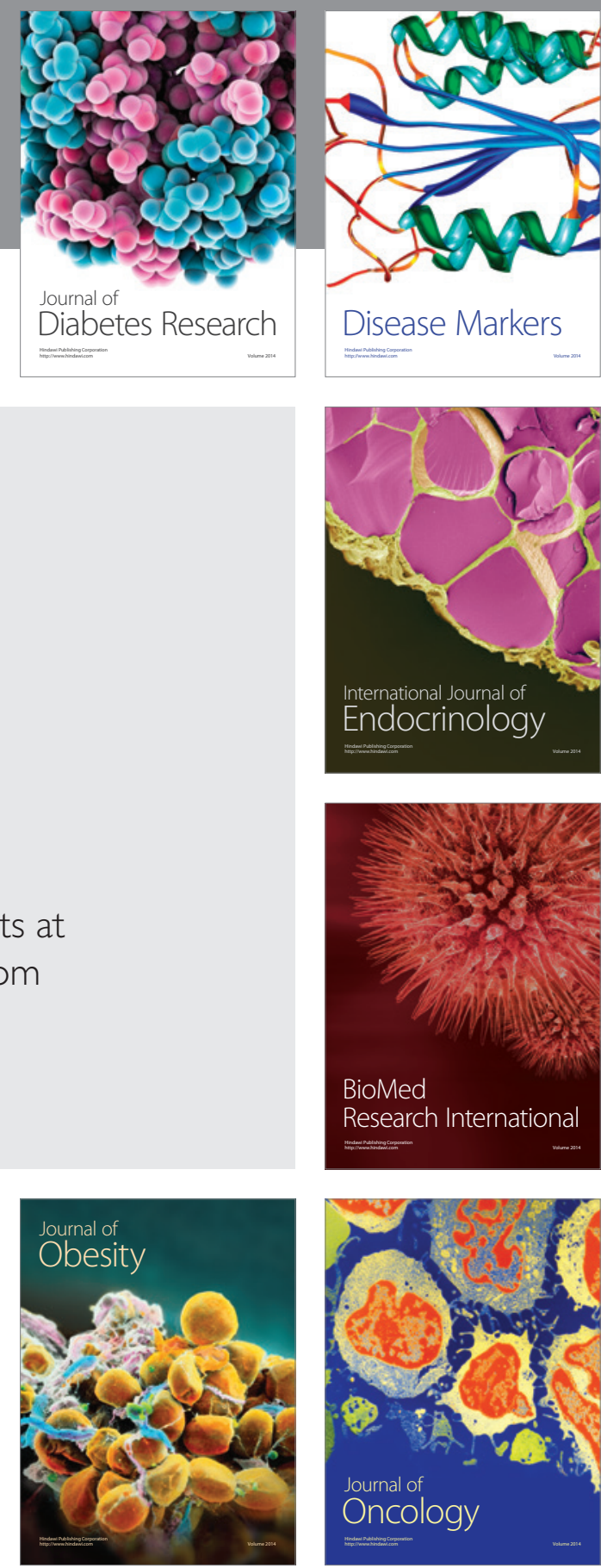

Disease Markers
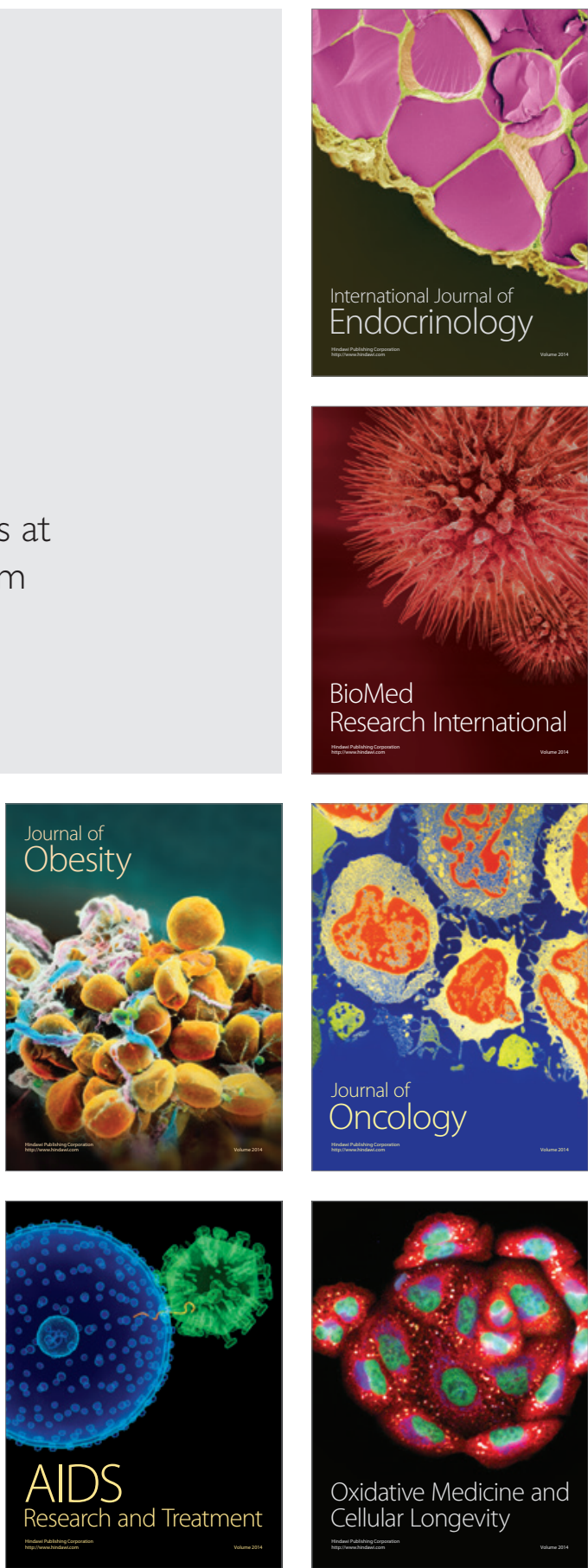